\title{
PROLOGUE: HUMAN GOD-TALK AND GOD'S SILENCE
}

\section{Edward Schillebeeckx}

Religions are no longer primarily associations that endorse particular belief systems, but rather are traditions of religious experience (as I call them in several of my books). My assumption here is that any understanding of truth has a "tradition-conditioned" character, even in the matter of religious truth; hence we have "human traditions" (the term is Walter Benjamin's) and traditions of religious experience. No one begins at point zero, and if one does, one comes back empty-handed.

\section{ReLigious By NATURE?}

The great world religions do not fall into the same genus, the genus of religion, like plants, animals, and people who, despite their differences, all are part of the genus of living beings. Of the many different kinds of religion, one can speak (with Wittgenstein) of family resemblances. If the world religions were to understand that, they would interact in a more friendly way-we would have basically a kind of "ecumene."

Personally, I would call the religions wisdom schools. They are schools that on the one hand, preserve us or liberate us from idolatry, that is, from the tendency to honor and adore something finite (this is something I learn from the Jewish school and the Christian school that emerged from it). On the other hand, they are schools that try to purify our cravings and desire (something I learn from the many branches of Hinduism and Buddhism). Religions are not systems of truth constructs; they try to trace a way of life, albeit not without truth and insights. The first name for the Christian Jesus movement was not 
Christians or Christianity, not to mention Christendom. It was he hodos, "the way" (especially in the Acts of the Apostles).

Human beings are "religious by nature." This does not mean to imply that God exists; only that everyone (except perhaps for the cynical nihilist) has a kind of holy place somewhere in them, something that is unconditionally at their center. The question, therefore, is not whether we honor a god, but which god we honor and adore. This is the principal question, especially in a secularized culture. Secularized people will never call the gods they honor in their everyday lives (for example, mammon) their god. Everything but that. But that this is what they in fact do is craftily camouflaged. Human beings have no other choice than to set their hearts on something. They all have something sacred, unassailable, something worth living for, something worthy to engage their hearts, their minds, and all their senses. They commit themselves unconditionally to this. That's the way human beings are.

But if their god or idol is a creature, there can be destructive consequences that will consume human beings themselves. Think of the Holocaust, and the many new holocausts in the former Yugoslavia, in Rwanda, Burundi, Congo, Northern Ireland-one could go on and on. Unconditional surrender to nationalism, the state, mammon, the economy, whatever; to those who worship the left or the right or the middle, to those who regard opportunistic political parties as the goal or the summum bonum - all of this leads to catastrophe, to violence, to the loss of the other's sense of personhood, and even to genocide.

The same happens when the religion itself becomes an idol, albeit camouflaged and disguised, when it acts "in the name of the true God," in the form of unconditional struggle to maintain itself alone, when it will not relinquish positions of power, when it enriches itself financially at the cost of its own believers. When that happens, religious wars and inquisitions come about, and take up the use of force "in the name of JHWH," or Allah, or Christ the King. To be sure, some modern evangelists do the latter with charm, but with an all the more clever religious brainwashing.

The question as to which god you worship has to do with whether your heart is focused on the destruction of others, or on peace and freedom for each person; on solidarity, justice, and love; on friendship, gift of self, and the loss of self in the service of others, if necessary. We must be honest: being religious by nature, having a need for unconditioned 
commitment, can be extremely dangerous precisely when it becomes a human need and craving. Humans are, after all, also by nature idolaters. We cannot forget that human desire is a creature (and thus ambivalent), and whoever raises a creature to the glory of divine majesty is an idolater, certainly no servant of the divine mysteries. One can also swim in self-absorption in the "divine-sacred."

Let us not forget that when it is a matter of the true God, the living God of all human beings, believers cannot downgrade God to give themselves an unpaid upgrade. To adore God has its costs. If we do not pay the price of giving ourselves over, we run into all kinds of dangers at every turn. One of these, to my mind, is the much-heard appeal today to "the ineffable God of which (or whom) we must be silent." Silence about God: a slogan of postmodernism. Long before the term postmodernism was in fashion, the philosopher Wittgenstein wrote, "of that which we cannot speak we must be silent" (Tractatus LogicoPhilosophicus, New York: Humanities Press, 1961, no. 7, 151). Elsewhere he added to this that it is precisely in that undiscussable zone that the deepest human problems of life are hidden, waiting for an answer.

\section{The Dialectic of Speaking and Being Silent}

What is at play here is a dialectic of speaking and being silent. The question at the heart of religious experience can be formulated in this way: How can God be named? How can the ineffable be brought to words? The path of Christian wisdom is this: You must let go of your heart to the ineffable divine mystery, but in doing so at least some words must be spoken. Something gets the name divine, after all, if you honor it as that which, or who, is "the end" (the be-all or end-all). But it cannot be something or someone from our creaturely world, not even the totality of this finite world. Worship is proper to the concept God, it belongs to that concept; otherwise we are talking nonsense.

God is not God for himself. The mystery of God, at least for us human beings, is called God by those worshipping creatures who honor him - by us human beings. Jacques Pohier did not call his book (deemed heretical) Quand je dis Dieu ("when I say God") for nothing. Our enunciation of the name God, that is, "I say God," does not call 
the divine mystery into being. God's silence actually makes it possible that I sometimes have to cry out the name of God in tears. Without the worship of human beings, the divine mystery is never God.

But there is a lot of carelessness and lack of economy at play in much talk about God. God is, rather, the mystery with which no thing or person or image or power, nothing in this world, or even the world in its entirety, can be identified. On the other hand, the living God is transcendent to the degree that he dwells in the utmost depths of our selves, and we are like fish in divine water. $\mathrm{He}$ is more intimately close to us than we are to ourselves-interior interiori meo, as the Christian neoPlatonist St. Augustine put it. He was able to say that because of God's real transcendence. Zoologists have told me that fish, despite all the swimming they do in the water, are the last to discover that they are swimming in it - that it is the living source of their existence in which they live, move, and have their being.

But caution is advised here as well. The modern term negative theology, being silent about God, can be misleading. It is certainly not what the patristic period called apophatic or wordless theology, or what medieval (especially Thomist and Dominican) theology called the via negativa. At the heart of all the great world religions, there flows a mystical undercurrent of being silent about God. This is not not talking about God at all (although there are some interreligious differences here). Every serious religion has something like a ban on images (even if they also say that you may use images). All images are smashed. However necessary that may be, it becomes a purely hate-filled iconoclasm if you are not empowered to do this smashing of imagesin other words, if all your denials do not find their power or springboard to negation in a positive recognition of God's untouchable holiness, or sacrality.

All denials presume an unexpressed but positive realization of what God is. Otherwise, you could not or even would not dare smash those human images of God. You know that they cannot be up to representing the reality of God, that is, that your human speaking about God does not make the grade at all. No single image, no single representation, no experiential or abstract concept is in a position to speak of God on God's level. Put another way, we have no concepts of God. Religious discourse is symbolic and metaphorical discourse. This is not a lower level of understanding, but precisely an awareness of a level 
higher than all rationality, a level that transcends our concepts, our capacity to form images and definitions. When we can no longer articulate something even while its name burns our lips, we poor, feeble beings do it with some artifice as the only way out.

The cognitive power of symbols and metaphors surpasses the assertive eloquence of all our concepts, and surpasses the theological concept (which some theologians use) of God as a human cipher of God, which can only be verified eschatologically, as the British theologian John Hick puts it. For it is only then that we shall "see," as Paul says, "face to face." Here on earth, it remains all artifice; even Paul had to use a mirror for it.

\section{YeT WE SPEAK OF GOD!}

With all our awareness of the silence of God, we must have the courage to speak of God. The distinction between God and the world is from our perspective, not that of God. Thus the relation of dependence between the world and God is not mutual (as Thomas already had pointed out), but there is a mutuality of real contact between God and the religious person, at least in the mind of the Christian tradition of experience. A form of life that knows no form of responsive speech and, thus, always stops with silence is, in any event, not the form of life of Jesus of Nazareth, whom Christians confess as the God's first love and eschatological witness.

Without exception, there is an absolute priority of God's grace on all that human beings think, do, feel, and say. To speak as human beings is always a response. Playing around with being silent about God is, to my mind, not speaking about God at all and, moreover, being silent about Jesus of Nazareth as the dialogue or word of God. As mere creatures, we acknowledge the inadequacy of our discourse about God by speaking about God with economy and care. But if, following modern positivism, a literal, computer-like descriptive knowledge becomes the only paradigm of all human knowledge (and that threatens to become the dominant one in the positivistic West, even in some of the secular and Christian universities), then everything falling outside that paradigm is sheer nonsense, including every form of religion. Then the only voices we can hear on earth (since this makes nature mute) are the voic- 
es of those people crying in the wilderness, screaming in the cosmic darkness, who brought even a Blaise Pascal to fearful astonishment.

\section{Being Silent about God as Counterpoint to Speaking about GOD}

Christianity is distinguished from philosophical agnosticism, and also from all postmodern silence about God, by the way it addresses-speaks to-Christian "unknowing." Christians speak to the Mystery right through the darkness. They respond surprised to the quiet that surrounds us, and that we allow to enter our interiority (for interiority is full of the exteriority from outside). This has to do with a silence that is recognized as the voice of God. God does not come "in storm, loud noise, and fire," as was the case in the first years of Israel, but in the lisp of a whispering voice. Thomas says: Deus non est existens, sed supra existentiam ("God does not exist, he transcends all existence," Summa Theologiae I, q. 12, a. 1, ad 3). Elsewhere he says, De Deo scire non possumus quid sit, sed quid non sit ("we cannot know what God is, but what he is not," Summa Theologiae I, q. 3-13).

But to say something like that, you have to know something positive about God; otherwise it is nonsense. We hear about the same thing from India: God is neither sat (not an existent being) nor asat (not stillness, not emptiness, although you must make yourself empty to receive it). God is neither of the two. We can correct the converse of an expression about God only by another converse expression (that is the tenor of Thomas's analogical speaking about God). But then you had better know what this divine mystery means regarding majesty and lure for people who maintain that God is ineffable. Because oscillating between "it is not this" and "it is not this either," and so on, is an endless dialectic of "warm or cold" that will never excite anyone.

I have already said that all great religions at their very best are schools of wisdom and freedom. In the first place, they want to protect us against the veneration of creaturely idols, against idolatry, against offering to a creature the worship that is only to be accorded to the divine mystery. Idolatry is a worship of an object upon which the glory of God has come down, or a thing upon which human beings project their own 
unsatiated desire and glory. I always think of the illuminating story of the burning bush (Ex 3:1-15), the place where God is present is not God. Where God is, is not God. If God is present in a person, in an event, in a dream or in a project, then we take off our shoes; we bow down and may well offer sacrifices, but that person, that event, that vision is not God. The sacrality of God's presence is never divine. God manifests himself in our acknowledgement of his holiness, that which lies behind our understanding, our control, our manipulating or our managing. It lies behind any knowing that wants to cast a net or a defining project over the mystery, in order to fish something meaningful out of it.

On the other hand, wanting to pause or stop by the dark night of the soul, the Cloud of Unknowing, the cloud of the ineffable, is itself also a form of idolatry. Then we are making an idol of the darkness. Medieval Flemish mystics (was it Hadewijch or Ruusbroec? It is still debated) tried to escape the idolatry of being silent in their via negativa by talking about something like a "dark light." A more paradoxical metaphor is unthinkable, but it does come near this reality, albeit from a creaturely point of view. The seductive power of idolatry also finds expression in various forms of worship of the void. But neither the darkness, nor even the gentle breeze is God: both merely point to the divine mystery that, in its quickly passing us, allows us only to see "its back," as it says in the story of Moses.

We may not make an object of the darkness or the silence before which we may pause to give our adoration. To do so is to make an idol of silence, like the neo-Platonic Sige (the Great Silence); the silence that, according to the fourteenth-century Byzantine Orthodox mystic and theologian Nicholas Cabasilas, the divine ousia (nature or substance) pushed deeper into the unknown. But then he had to admit that that hidden substance radiated a certain aura-he called them divine energies - that had to, as it were, bridge the distance between the unknown, deeper divine nature and the more external divine Triune Unity. There is a suggestion here that needs to be taken to heart regarding the Triune God. The one and only God is by nature (a nature that is pure, absolute freedom) such that he reveals himself in the economy of salvation as the one God-Father, Jesus Christ (the Son), and Spirit. 


\section{Christianity and the Dialectic of Speaking and Being Silent}

How does Christian faith see this dialectic of speaking and being silent? From a Christian point of view, the silence of the darkness (which we cannot deny) is nonetheless interrupted by a voice that speaks, to be sure a human voice, but as "the Word once spoken, the Life once lived, the Death once endured" (as I once heard in the Anglican liturgy). That is to say, Jesus Christ, a human being just like you and me, not an icon of himself, but pointing toward the one God worthy of our adoration, gate of our prayer to the Father, as it says in the Letter to the Hebrews: "Consequently he is able for all time to save those who approach God through him, since he always lives to make intercession for them" (Heb 7:25).

Dying on the cross, Jesus addressed him whom he called his loving Father: "My God, my God, why," but then, in spite of it all, "into your hands I commend my spirit, my entire being." To release oneself into the infinite divine mystery has, although in the tonality of a human response, the tenor of the voice of God himself. I would phrase it this way: God's silence becomes God's speaking, God's voice in the responding voice of a human being, a recognition of God's unassailable holiness. God's silence as anti-word (answer or counterpoint). It is not for nothing that the Jewish Psalms call God "the Holy One of Israel." No human voice can speak of "that which is from above," if it is not a counterpoint to what has been whispered from above. Not in storm, loud noise, or fire, but in the mute voice of a light rustle, in the silence and the loud cry of the one dying on the cross, who despite the darkness lays his all that he has and does, all his very being in the hands of the unknowable mystery.

\section{DiALECTIC OF SUfFERING AND LIFE}

Jesus' paschal rising appears to be God's confirmation of Jesus' faithfulness in the course of his life; that is to say, the Father stood with Jesus despite the murder human beings committed against him. The mission of the Holy Spirit equally can be seen as divine affirmation, but through the apostolic witness of Jesus' disciples, who were reminded by the divine spirit of their fidelity to the life of Jesus, and of their witness to 
God's ratification of that life by God, the Living One, taking him to himself. Both salvific events are interpreted liturgically in two (or even three) different feast days (as Luke distinguishes them temporally). But they mark one and the same divine authentification of both Jesus' life lived consistently to the very end, and the apostolic witnesses to this divine ratification, thanks to the paschal gift of God's Holy Spirit to the disciples of Jesus.

All of this flows from the initiative of God the Father and points back, even in Jesus the anointed one, to the one God, the most holy mystery, who holds to his heart everything of life, from the heights to the depths, from ant and aphid to elephant and human being. He is a God of life, not of the dead, to whom he also gives a future.

Although it could be said that Christianity is the religion that least trivializes in its praxis the suffering of humanity, the Christian and the Christian mystic say: "Be not afraid: I am with you," or "I will be with you." This is the name of God, the name that the haggling Moses got out of God that God did not want to give to him. Shrewder than Moses, God did not let him check the divine passport, but gave him an honest answer, however evasive: "I will be there for you." The story suggests ironically: "You will have to settle for that name!" For God will, after all, also be there to judge the living and the dead. We will have to account for ourselves to the name of God. Christianity is above all the praxis of the reign of God, an entryway or pathway to the eschatological revelation of God's own name.

On the basis of the Jesus event, we can say that Christianity is about love as the way to God, but a love that is not silent about the price, the costs of loving. The disciples of the risen crucified one were inculcated with this: the light appears in the darkness. Matthew 25, in the Second or so-called New Testament, is the story in which it is most clear that the specific charge to Christians, as Christians, is to identify themselves with the least among human beings. That identification is the measure by which God, in Christ, will make the final judgment of human beings (whether or not they recognize Jesus as the Christ).

The trace of God is to be found especially in the face of the rejected and poor person looking at you. I would want to say to all future ministers of God's mysteries-faithful, deacon, priest, bishop, synod, or pope- that the church is not where you are, but where all the faithful, and especially the ministers of the holy mysteries, are, caring and help- 
ing, looking into the face of the poor. There is where you see the invisible God "as passing by." Yet be reminded that it was not the Jewish priest, not the levite, but the foreign Samaritan who did not pass by the wounded man, but rather took him in his care. And it was he who saw God as passing by!

Translated by Robert J. Schreiter 